\title{
The Competences Model of Competitive Process Engineer
}

\author{
Elmira R. Khairullina ${ }^{1}$, Tatiana V. Pochinova ${ }^{2}$, Lyutziya G. Khisamiyeva ${ }^{1}$, Zavgaria M. Sakhipova ${ }^{3}$, Liliya V. \\ Fedorova $^{4}$, Alsu G. Ablyasova ${ }^{5} \&$ Nailya N. Aksenova ${ }^{6}$ \\ ${ }^{1}$ Kazan National Research Technological University, Kazan, Russia \\ ${ }^{2}$ Institute of Technology Branch of Ulyanovsk State Agricultural Academy named after P. A. Stolypin, \\ Dimitrovgrad, Russia \\ ${ }^{3}$ Almetyevsk State Oil Institute, Almetyevsk, Russia \\ ${ }^{4}$ Bauman Moscow State Technical University, Moscow, Russia \\ ${ }^{5}$ Kazan National Research Technical University named after A. N. Tupolev - KAI, Kazan, Russia \\ ${ }^{6}$ Ulyanovsk State Agricultural Academy named after P. A. Stolypin, Ulyanovsk, Russia \\ Correspondence: Elmira Robertovna Khairullina, Kazan National Research Technological University, Russia, \\ Tatarstan, 420015, K. Marksa Street, 68, Kazan, Russia. E-mail: elm.khair@list.ru
}

Received: May 7, 2015 Accepted: May 16, 2015 Online Published: May 28, 2015

doi:10.5539/jsd.v8n3p250 URL: http://dx.doi.org/10.5539/jsd.v8n3p250

\begin{abstract}
The need to develop a competences model of competitive process engineer is due to the fact that his professional career is multifaceted and there are quite a lot of specializations, professional success in which is determined by the competitiveness of the individual engineer. In this regard, this article aims at developing a competences model of competitive process engineer. The model presented in the paper reflects the technological University students' individual personality traits which are more significant in their future professional activity, as well as individual targets in self-development of students' competitiveness - future engineers, that is especially important in the context of opportunities identifying for the forms and methods improving to design the individual self-development programs of students' competitiveness. The article also reveals persistently recurring seven types of individual self-development of students' competitiveness in their design and creative activity: heuristic, research, technology, practice-oriented, social, communicative and mixed types. The material of this paper are both of theoretical and practical value for scientific and methodological divisions in the development of programs for increasing the competitiveness of universities, as well as for faculty in courses of lectures developing for students of engineering specialties.
\end{abstract}

Keywords: the competences' model, competitiveness, process engineer, self-development, individual development programs

\section{Introduction}

In the real educational process the self-development of the students' competitiveness is most often carried out spontaneously in the course of their professional identity. This means that teachers can contribute to the professional development of the students' competitiveness by creating more favorable teaching conditions at the University. One of the important conditions is primarily the creation of situations of competition and competitiveness in the learning process.

The competitiveness the most effectively develops in conditions of competition and contest, that is in the process of competitive activity, so it is necessary for each University to develop a special goal program for the students' competitiveness increasing. This program can be differentiated on: a) types of educational institutions; b) age groups; c) type of activity (education, science, sports activities, leisure activities, etc.) (Andreev, 2003).

However, it is also important to design an individual program of self-development of the competitiveness for each student.

For what purpose we need to design individual model of the process engineer? This is necessary because the professional activities of the process engineer is multifaceted, there is quite a lot of specializations, professional success of which is determined by the competitiveness of the individual process engineer. While each of the 
engineering specialties also leads to the need of self-development of specific individual competitiveness.

It should be noted that engineering and technological activities are creative ones. In addition to it, each person is unique because of his individual set of personal qualities, professional competences, professional and life experiences, his own motives for activities, needs, etc. (Andreev, 2005; Sakhieva et al., 2015). So in the process of learning every successful student as a future process engineer, based on the complex of his own qualities, can create his own model of competitiveness, which in many respects will depend on the type of his personality, but also be based on the requirements of the relevant specialty.

It is important that the design of such programs was carried out on the scientifically proved basis and its methods must integrate with existing concepts from the field of individualization and differentiation of vocational training (Masalimova et al., 2014). Such views are reflected in the works of Andreev (1981), Grebenuk (2000), Kirsanov (1982), Makhmutov (1971), Bobienko (2005), Demchenko (2000), Chaynikov (2007), Khairullina et al. (2015), Ivanenko et al. (2015), Kochkaeva (2005), Kotlyar (2006), Masalimova \& Nigmatov (2015), Melnikova (2008), Mitina (2002), Ozernikova (2005), Romanova (2007), Sakhieva et al. (2015), Sapizhenko (2004), Tatur (2004), Fatkhutdinov (2005). The presence of individual programs of self-development of the students' competitiveness -process engineers' competiveness is essential for the future professional achievements of students -process engineers. While for each student is important to follow the path of self-development.

According to V. I. Andreev, the basic foundation of personal qualities which determine the competitiveness of the individual person is his capacity for creative self-development and creative self-realization, so the priority of education in the XXI century should be given to the paradigm: guaranteed quality of education through creative self-development and creative self-realization of personality. In other words, education will contribute to the development of man as a competitive person, if it is transformed into self-education, up-bringing into self-up-bringing, and development - into creative self-development and creative self-realization of the personality (Afanasyev, 2003; Belov, 2002). Therefore, the primary method of development of students' competitiveness in any University is the method of creative self-development and creative self-realization on the basis of certain pedagogical conditions.

Then the first step in the pedagogical system formation in the University should be the goals' design of future specialists' competiveness self-development. And on the basis of individual goals, it is advisable to build individual programs of professional self-development.

The achievement of the highest level of competitiveness of the future professional personality should become the main result of the pedagogical interaction between teachers and learners. Competitiveness is a system combination that combines a variety of skills and abilities to contribute to professional growth and achievement of high results in the process of creative self-realization of the student and not just a quality characteristic of the person and the professional. Competitiveness is a multidimensional characteristic that changes depending on the number of internal and external factors: competition in the labor market, specialists' personal qualities and professional competencies, experience, strategies of behavior, values' orientations, etc. Therefore, for each type of professional activity several different models of personality competitiveness can be designed (Andreev, 2006).

\section{Methodological Framework}

In the basis of this study there is a modeling method which is applied in various fields of scientific knowledge. In pedagogy the modeling method is quite widespread and it has important theoretical and practical significance. So, V. M. Polonsky (1987) believes that: "the Model is a system of objects or symbols which reproduce some of the essential properties of the original system. In the process of scientific cognition the model replaces the original object: the model study gives information about the original object... the model reproduces the structure of the original object, makes it almost irrelevant, remove everything what is insufficient. It serves as a generalized reflection of phenomena, but not identical with it" (Polonsky, 1987).

In fact it is the method of idealization that allows identifying the main and backbone features of the object. And if in the ideal model there are general and typical indicators and criteria of competitiveness so in individual models private ones are represented, qualities which are typical for a certain type of personality, especially his creative style peculiarities, etc (Andreev, 2006).

\section{Results}

\subsection{The Competences' Model of Competitive Process Engineer}

This model includes: motives and values; the desire and ability to self-development, self-realization; high professional competence; qualities for leadership; corporate competence; cultural humanitarian competence; socio-economic competence; abilities for creativity; high civic qualities; high moral qualities; communicative 
competence; adaptability.

Let's consider these components in much detail.

\subsubsection{Motives and Value Orientations}

The motives and values of competitive process engineer are characterized by steady, conscious and positive attitude to his profession; motivation for professional activity in the future; motives of mastering his chosen profession at a high scientific-theoretical level using information from related fields of knowledge; the work for good results of professional activity; the pursuit for the highest quality of engineering and technological product; positive sustainable motivation to self-education and self-development; the interests to cognitive process.

The most important for the development of competitiveness is the unit of students' - future process engineers' motives and values development. Effective implementation of engineering and technological activity requires the integration of essential skills and abilities, on the base of which can be formed competences groups required in the future, however, motivational-target basis must be created for their self-development.

The forming competitiveness qualities should include not only technological competences but also general mental attitude of the individual to achieve effective results in engineering and technology activities, personal competitiveness development. The motivational value orientations on self-development of competitiveness in the learning process are the starting point, the basis for students' engineering and technological competencies development and self-development.

\subsubsection{The Desire and Ability to Self-Development, Self-Realization}

The ability to self-development is the basis of the evolution in living life. Living organisms are self-developing systems. Ability to self-development and personal self-realization lie in the basis of personal and professional development. Currently the specialist's work is evaluated not only from the point of view of professional activity, but also from the point of view of possibility to develop his creative potential and non-standard thinking, so there is an acute problem of the revision of the outlook on teaching within a framework of continuous self-perfection.

\subsubsection{Civil Qualities}

These qualities involve civic responsibility, humanism, patriotism, tolerance, progressive views and much more. All this things is also necessary to develop in a student's personality - future process engineer.

\subsubsection{High Professional Competence}

High professional competence despite of the key competencies development required for the project activities implementation involves knowledge of methods for modeling, design, and forecasting, as well as methods of research and testing needed to create new intellectual property and material engineering and technological products; the ability to conduct pre-analysis of the project, free skill for operation with technical literature, normative and regulatory documents for design and technological activities; skills to work on various research projects; knowledge of systems analysis principles; ability to prepare design documents of technical design sections, as at the primary design stage so at the detailed design stage; the ability to work in a context of complex engineering tasks of design, including knowledge of design peculiarities in related engineering sections, etc.

\subsubsection{Leadership Qualities}

Leadership skills involve skills in organizational activities, the ability to protect engineering project among the customers; ability to establish and maintain a safe healthy environment and working environment in production team; the ability to conduct supervision over the technological products' implementation; the ability of the specialist organizer in engineering and technology design and the ability of a public figure with great powers and responsibility, ability to make decisions and take responsibility for the results of his own activities.

Such competences are developed in the classroom, associated primarily with the collective decision making in practical problems' solving during the implementation of design and creative work, using techniques and methods of cooperation and implementation of the necessary rules in design and creativity activity.

\subsubsection{Corporate Competence}

For process engineer it is important to develop corporate competence, as he often deals with collective projects. In this regard, it is important to be able to collaborate, share ideas with colleagues, i.e. to work in a close-knit creative professional team.

\subsubsection{Cultural Humanitarian Competence}

General cultural humanitarian competence involves the formation of a specialist on the basis of rational 
combination of general, humanitarian, technical, economic and artistic spheres of education through strengthening interdisciplinary connections in teaching, mastering of reference leading knowledge and application of this knowledge to solve diverse problems of creating modern engineering technology.

\subsubsection{Socio-Economic Competence}

This kind of competence involves the development of a specialist who understands the laws of social development with economic-organizational skills (to make contracts, to assess the socio-economic and socio-demographic situation in the region, etc.), knowledge of methods of technical and economic analysis of his activities with a view to its successful rationalization.

\subsubsection{Creativity Abilities}

Creativity abilities involve the development of a specialist with a high creative potential and creative thinking, compositional skill. Students - future engineers must be specially trained the methods of creative self-realization, the goal of education here is also improving the efficiency of the educational process.

Cognitive styles of engineering creative activity, as well as certain individual qualities can be involved in this block. The success of future process engineer's activity is largely determined by his creative style of activity. The style is characterized by a flexible professional behavior on a number of specific situations and spheres of his activity and it depends on the intellectual level of the individual, personal qualities and development of his competences, on the level of their creative application in a particular professional situation.

Important qualities are tolerance and also the aesthetics of the thinking of the student - future process engineer. For the future process engineer is very important his aesthetic training. It is fulfilled not only in the process of implementation of design and creative work, but also by means of the entire educational process.

The concept of "aesthetic training" is seen as a unity of aesthetic education and up-bringing, implemented in the content, diverse forms and methods of educational work, extracurricular events, it covers the entire period of study at the University. It is professionally oriented. The aesthetics of the educational process is reflected in the content of subjects, in the choice of forms and methods of training which are most appropriated to the content of the studied material, intensifying the students' activity; pedagogical and methodological skills of the teachers, his emotional attitude to the subject of teaching, the ability to create aesthetic moments and his relation to the students' audience (Laurenovich, 1989).

\subsubsection{Communicative Competence}

Communicative competence involves the ability to work in a creative team, possession of communication skills, etc. This unit includes a whole range of important for self-development of the students' competitiveness psychological qualities which contribute to effective interpersonal and personality-oriented communication in their future professional engineering and technological activities.

It is desirable for students to develop regulatory and orientation quality, which contributes to the development of such communication skills as the correct orientation in the partners, in social relationships, in a variety of situations for communication, skills accounting behavioral responses of others. These qualities are most efficiently formed in the game forms of learning activities.

It is very important for the future process engineer to respect his customers and this implies self-developed ability to be attentive to their reasoning, the ability to listen and desire to understand the other, the willingness to admit error and the correctness of the customer.

\subsubsection{Adaptability}

Adaptability implies a high stress resistance of the specialist, orientation to a healthy lifestyle, the culture of mental and physical labor, as well as the culture of appropriate behavior in society.

It should be considered that the perfect competitive model of the process engineer is some idea about the professional ideal: the ideal model provides a more generalized view of it, whereas the personality model is based on specific qualities and development and self-development factors of the specialists' competitiveness (Andreev, 2006).

Having created his own program, it is important for the student to ensure regularity in the classroom for self-improvement, choosing a certain way of life and learning in the University in accordance with the selected program. Thus it is still desirable to have guidance of a competent teacher. Developed program should be compared with other programs of self-development to correct it - this can speed up the expected results. 


\subsection{Types of Individual Self-Development of Students' Competitiveness in Their Design and Creative Activity}

We identified persistently recurring seven types of individual self-development of the students' competitiveness in their design and creativity activity.

1. A heuristic type which is characterized by the dominant ability to generate new original ideas in design and creativity activity.

2. Research type, which is characterized by the ability to effectively application of scientific research methods in design and creativity activity.

3. Technological type, which is characterized by a focus on a thorough development of the technological part in the design and creative activity of students.

4. Practice-oriented type, which is characterized by the orientation of the design and creative activities at the practice, i.e. the practical implementation of the project.

5. Social type, which is characterized by orientation on socially significant goals and objectives in the performance of design and creativity activity.

6. Communicative type, which is characterized by the ability to make public presentations, effective discussion of the results of design and creative work, as well as the desire and ability to corporate design and creative activity.

7. Mixed type, which is characterized by the effective integration of a variety of competences and abilities in the design and creative activity of students - future process engineers.

\section{Discussions}

The individual models design of competitiveness of the process engineer professional personality must be based on a detailed study of the personal characteristics of students, their goals, values, needs, motives, abilities, etc. In order to allow students to create individual programs of competitiveness and really become competitive, they need to be focused on self-cognition of their advantages and disadvantages.

Then students need to undertake in-depth study of themselves (be aware of themselves) and means that can contribute to the development of the necessary professional competencies and personal qualities, so each student should and can become a teacher for himself, this way must be passed by each student independently. There is nothing bad that a lot of mistakes is made, they are the source of learning and self-development. Each student must discover the truth of cognition for himself and to be relatively independent of the others.

So, it is crucial that an individual program of competitiveness self-development is developed by the student. The teacher's task is to help him in this.

\section{Conclusion}

Thus, the presented model of competences of competitive process engineer includes: motives and values' orientations; the desire and ability to self-development, self-realization; professional competence; leadership qualities; corporate competence; cultural humanitarian competence; socio-economic competence; ability to creativity; high civic qualities; high moral qualities; communicative competence; adaptability.

It is also necessary to design individual models and programs of competitiveness' self-development for each student. This is necessary because the professional activities of the process engineer are multifaceted and there are a lot of specializations, professional success of which is determined by the competitiveness of the individual engineer. While each of the engineering degree leads to the necessity of specific competitiveness self-development.

The article also suggests seven competitiveness individual models of the student - future process engineer which are designed on the personality typology basis of the technological University students: the heuristic, research, technology, practice-orientated, social, communicative and mixed types.

\section{References}

Afanasyev, A. N. (2003). The Bologna process in Germany. Higher education today, 5, 15.

Andreev, V. I. (1981). Heuristic programming teaching and research activities: method. Benefits. Moscow: Higher. School, 240.

Andreev, V. I. (2003). Pedagogy: Course for creative self. Kazan: Innovation Center, 608.

Andreev, V. I. (2005). Pedagogy of higher education: Innovation and prognostic course. Kazan, CIT, 499.

Andreyeva, Y. V. (2006). Orientation training journalism students to self development of competitiveness. Kazan, 
Innovation Center, 300.

Belov, A. V. (2002). System of education quality assessment. Higher education in Russia, 1, 44-49.

Bobienko, O. M. (2005). Key competences of the person as a result of the educational system of vocational education (Unpublished master's thesis). Kazan, Univ. Kazan, 186.

Chaynikov, V. N. (2007). The competitiveness of enterprises. Tambov: Publishing House of the Thumb., 192.

Demchenko, A. A. (2000). Measurement of industry competitiveness: the theory and methods of measurement. Kursk, GUIPP "Kursk", 87.

Fatkhutdinov, R. A. (2005). Competitiveness: Russia and the world. Moscow: Economics, 605.

Grebenuk, O. S., \& Trebenyuk, T. B. (2000). Fundamentals of pedagogy personality. Kaliningrad, 319.

Ivanenko, N. A., Akhmetov, L. G., Lavrentiev, S. Y., Kartashova, E. P., Lezhnina, L. V., Tzaregorodtzeva, K. A. \& Khairullina, E. R. (2015). Features of Modeling the Formation of Teaching Staff Competitiveness. Review of European Studies, 7(3), 37-42. http://dx.doi.org/10.5539/res.v7n3p37

Khairullina, E. R., Valeyev, A. S., Valeyeva, G. K., Valeyeva, N. S., Leifa, A. V., Burdukovskaya, E. A., \& Shaidullina, A. R. (2015). Features of the Programs Applied Bachelor Degree in Secondary and Higher Vocational Education. Asian Social Science, 11(3), 213-217.

Kirsanov, A. A. (1982). Individualization of educational activity as a pedagogical problem. Kazan, KSU, 244.

Kochkaeva, T. N. (2005). Valuetargeted priorities of modernization of contemporary Russian art education. Social humanities, 6, 53-64.

Kotlyar, B. A., \& Medvedev, A. Y. (2006). Social Partnership and competitiveness. Moscow: Typography "News".

Laurenovich, E. A. (1989). Aesthetic training of future teachers in connection with the study of a foreign language. Aesthetic education of students in the learning process: Interuniversity collection of scientific papers. Riga: Latvian state: University. N. Stuchki, 82.

Makhmutov, M. I. (1971). Questions organization process problem based learning. Kazan: Kazan University, 63.

Masalimova, A. R., \& Nigmatov, Z. G. (2015). Structural-Functional Model for Corporate Training of Specialists in Carrying Out Mentoring. Review of European Studies, 7(4), 39-48. http://dx.doi.org/10.5539/res.v7n4p39

Masalimova, A. R., Schepkina, N. K., Leifa, A. V., Burdukovskaya, E. A., \& Shaidullina, A. R. (2014). Mentoring perfection in modern enterprises conditions: practical recommendations. American Journal of Applied Sciences, 11, 1152-1156. http://dx.doi.org/10.3844/ajassp.2014.1152.1156

Melnikova, A. Y. (2008). Engineering games as a pedagogical means of formation of innovative potential of future specialists (Unpublished master's thesis). Orenburg State: Univ. Orenburg, 24.

Mitina, L. M. (2002). Developmental Psychology competitive personality. Voronezh: Publishing NGO "MODEK", 400.

Ozernikova, T. G. (2005). Motivation and competitiveness of employees: relationship problems. Proceedings of ISEA, 1(42), 71-75.

Polonsky, V. M. (1987). Assessment of the quality of scientific and pedagogical research. Moscow: Pedagogy, 144.

Romanova, M. V. (2007). Development of information competence of students of the University. Magnitogorsk, Magnitogorsk State University, 168.

Sakhieva, R. G., Ibatullin, R. R., Biktemirova, M. K., Valeyeva, G. K., Pchelina, O. V., Valeyeva, N. S., Minsabirova, V. N., \& Khairullina E. R. (2015). The Essential, Objective and Functional Characteristics of the Students' Academic Mobility in Higher Education. Review of European Studies, 7(3), 335-340. http://dx.doi.org/10.5539/res.v7n3p335

Sapizhenko, V. V. (2004). Formation of competitiveness of the administrative personnel of large industrial enterprises of electronic resources (Unpublished master's thesis). Irkutsk, 147.

Tatur, G. (2004). Competence in the structure of the model of specialist training. Higher education today, 3, $20-26$.

\section{Copyrights}

Copyright for this article is retained by the author(s), with first publication rights granted to the journal.

This is an open-access article distributed under the terms and conditions of the Creative Commons Attribution license (http://creativecommons.org/licenses/by/3.0/). 